\title{
MAIN VARIABLES THAT ARE INFLUENCED BY THE ANTHROPIC ACTIVITY RESULTING FROM THE SOYBEAN PRODUCTION IN THE MUNICIPALITIES OF MATO GROSSO
}

\author{
Rodrigo Carlo Toloi \\ IFMT Rondonópolis/UNIP, Brazil \\ E-mail: toloirodrigo@gmail.com \\ Alexandra Cristina Ramos da Silva Lopes Gunes \\ FEUP, Portugal \\ E-mail: aslopes@letras.up.pt \\ Marley Nunes Vituri Toloi \\ IFMT Rondonópolis/UNIP, Brazil \\ E-mail:Marley.toloi@gmail.com \\ João Gilberto Mendes dos Reis \\ UNIP, Brazil \\ E-mail: betomendesreis@msn.com
}

Silvia Helena Bonilla UNIP, Brazil

E-mail: shbonilla@hotmail.com

Moacir de Freitas Junior FATEC ZS/UNIP, Brazil

Submission: 29/03/2018 Accept: 29/03/2018

\section{ABSTRACT}

This study aimed to identify how the main variables that are influenced by the anthropic activity resulting from the soybean production in the Mato Grosso Municipalities cluster among themselves. Factor analysis method was used to identify underlying dimensions that can account for the shared variation of observed variables. The factorial analysis proposes to reduce the number of variables by the extraction of independent factors, so that a better explanation of the relationship between the original variables occurs, avoiding correlational problems and reducing the relevance of endogeneity. Three dimensions were identified, each with a different combination of variables. 
INDEPENDENT JOURNAL OF MANAGEMENT \& PRODUCTION (IJM\&P)

http://www.ijmp.jor.br

v. 9, n. 5, Special Edition IFLOG 2017

ISSN: 2236-269X

DOI: 10.14807/ijmp.v9i5.812

Based on the results from principal components modelling it is fair to state that the impacts of the anthropic activity resulting from soybean production in the Mato Grosso municipalities can be analyzed according to three main domains: production impacts, socioeconomic impacts and demographic impacts. The main contribution of this paper is that it offers a useful framework of analysis for both public and private decision-makers regarding the influence of soybean production on economic, social, environmental, and cultural factors.

Keywords: Anthropic Activity of Soybean; Multivariate Statistical Analysis; Environmental; Social; Economic Factors

\section{INTRODUCTION}

The improvement of public policies for the production and export of Agribusiness Commodities was driven by the increase in demand for soybeans, mainly to produce oil for human consumption and animal feed meal.

According to data from the Foreign Agricultural Service (FAS) of the United States Department of Agriculture (USDA), China, the United States, Brazil, Argentina, and the European Union consumed in the 2015/16 crop the amount of 408.8 million tons of soybean (Grains, Bran, and Oil), of which China consumed $30.6 \%$ followed by the United States (17.3\%) and Brazil (12\%) (FAS/USDA, 2016).

China stands out as the world's largest soybean importer, in the 2015/16 crop, Brazil collaborates with more than $63 \%$ of the soybeans destined for the Chinese market. The Chinese demand for soybeans meets the domestic consumption of soybean oil and soybean meal. It is estimated that in the next decade, the volume of 57.2 million tons of soybeans will be imported, which is equivalent to $56.1 \%$ of world grain imports (FAS/USDA, 2016).

In this scenario, Brazil has consolidated its position as the second largest producer and the world's largest exporter of soybeans. As of the 2012/13 harvest, it exceeds in quantity the exports from the United States, while Argentina, third place in the ranking of grain production, has presented decreasing exports of soybean.

The Brazilian exports of the soybean complex accounted for $14.6 \%$ of the export tariff for 2015, equivalent to US\$27.96 billion, of which $75.1 \%$ were 
soybeans, $20.8 \%$ bran and $4.1 \%$ of refined oil (LOPES; FERREIRA; LIMA, 2015; MDIC, 2016).

At the beginning of the 1980 s, the Central-West states occupied $14 \%$ of their soybean area, compared to $77 \%$ of the southern region, but from the 1990 s, this scenario began to transform, and already in 1998, the states located in the centralwest region had $45 \%$, while the southern region reduced its area to only $48 \%$ (PAULA; FAVERET FILHO, 1998).

The increase in the area of soybeans planted in the Midwest, to the detriment of the planted area in the South, can be explained by the migration movement of the Southerners, especially from Rio Grande do Sul and Paraná, toward the Central West. They went to Mato Grosso, Mato Grosso do Sul, and Goiás, expecting to increase the amount of land they had in the south of the country (LUEDEMANN, 2009).

Thus, it is observed that anthropic activities related to soy production have consequences in the economic, social, and environmental spheres. Measuring these influences, as well as evaluating interactions and feedback, implies methodologies that can deal with this complexity.

The response to anthropogenic pressure can be represented by a series of variables that represent economic gains, influence on social dimensions, including health, education, but also the depletion of local resources and loss of biocapacity.

In this sense, the present study seeks to identify the main variables that are influenced by the anthropic activity resulting from the soybean production in Mato Grosso's municipalities.

The choice of variables implies a series of considerations, starting with the selection of relevant variables, their availability, and the appropriate treatment to avoid redundancy.

This avoids the adoption of variables that do not contribute to the diagnosis and allows for the optimization of decision-making and adoption of public policies in a faster and more efficient way. 
The Factor Analysis method was chosen to integrate the results of the variables adopted, to show correlation and interdependence, and to allow the aggregation of data.

To meet the proposed objective, the article is organized with this brief introduction, followed by a Literature Review section. The third section presents the methodology that was used, and in the fourth section, we present the analysis and discussion of the results. In the last section, we present the final considerations.

\section{LITERATURE REVIEW}

Aiming to present the environmental, economic, and social contribution that soybean production promotes in the municipalities of the State of Mato Grosso, in this section, a brief review will be made on the literature available on this subject.

\subsection{Environmental, Economic, and Social Influence of Soybean Production in Matogrossense Municipalities}

In the environmental field, it is possible to observe changes in legislation, operational, and management practices resulting from competitive pressures from external markets and, especially, from raising society's awareness of environmental issues and the impact of soybean production on the development of society (ZHU; SARKIS, 2004).

Such changes in the operational and management practices can be observed by the adoption of Innovative Agricultural Technologies, which began to appear in Mato Grosso in the 80's, such as the use of direct planting (PRUDÊNCIO DA SILVA et al. 2010).

Direct planting was introduced to alleviate the problem of soil erosion, which directly leads to loss of efficiency of agricultural production, and indirectly leads to the silting of nearby rivers and lakes (RODRIGUES, 2005), which are contaminated by heavy metals of fungicides and chemical fertilizers (CAVALETT; ORTEGA, 2009).

However, other measures to prevent soil erosion, which directly entails the silting of rivers and lakes and soil impoverishment, and indirectly contributes to contamination of water and soil resources, have been implemented, such as the Rotation of Culture, Integration of Farming-Livestock-Forestry (and its variations), 
INDEPENDENT JOURNAL OF MANAGEMENT \& PRODUCTION (IJM\&P)

http://www.ijmp.jor.br

v. 9, n. 5, Special Edition IFLOG 2017

ISSN: 2236-269X

DOI: 10.14807/ijmp.v9i5.812

Sanitary Void, Biological Pest Control, as suggested in several studies (BINI, 2016; CAVALETT; ORTEGA, 2009; RODRIGUES, 2005; SOARES, 2016).

Gibbs et al., (2015) points out that deforestation is an activity that needs to be controlled, and highlights that between 2001 and 2006, soybean plantations expanded by one million hectares, only in the Amazon biome.

Another factor that has been the subject of discussions about the effects of soy production is the high reliance on productive inputs, such as fertilizers, fuels, machinery, and pesticides, which contribute to the increase of greenhouse gas emissions (GHG) (RAUCCl et al., 2015).

According to Teixeira; Faria; Zavala (2013) soybean production has been one of the main factors responsible for the emission of $\mathrm{CO}_{2}$ in the State of Mato Grosso. Emissions in the state are due to crop residues, the use of fuels and fertilizers and the incorporation of new productive areas.

According to Lindoso (2009), in 2006, soybeans emitted the equivalent of 3.5 million tons of $\mathrm{CO}_{2}$, and the use of fertilizers in the crop was responsible for emitting 830,000 tons of $\mathrm{CO}_{2}$.

Among the main GHG Emission Factors (FE) in soybean production in Mato Grosso, the use of fossil fuels, fertilizers, crop residues, electricity, pesticides, seeds, biological nitrogen fixation (BNF) and deforestation to incorporate new areas for production (LINDOSO, 2009; RAUCCI et al., 2015, TEIXEIRA; FARIA; ZAVALA, 2013).

As for the economic aspect, according to Fagundes and Siqueira (2013), the soybean crop takes an important position as an agricultural activity that generates employment and income, moving a series of economic and institutional agents, all its complexity and reach of its productive process. This is a dynamic and demanding sector of innovations and constant investments due to the high degree of competitiveness in the current market.

According to Anholeto and Massuquetti (2014), the soybean crop has stood out in relation to the Brazilian crops, providing greater income to the producers and foreign exchange to the country, precisely because it is a product with a wide chain of production from the manufacture of inputs to the final consumption. 
With the expansion of the area, the modernization of machinery and equipment and the technology used to grow soybeans, aiming to improve production and increase incomes, we can see the increase in the number of jobs, and in 2010, the productive activity was responsible for $60.6 \%$ of the country's income generation.

These factors, together with the genetic improvement of seeds and more productive planting systems, besides contributing to the generation of employment and income, contributed to the increase of soybean production and productivity in the Midwest region of the country (KUMAGAI; SAMESHIMA, 2014).

In addition, flatland supply and climate regularity enabled Mato Grosso to achieve higher national productivity, with $2,730 \mathrm{~kg} / \mathrm{ha}$, compared to a national average of 2,406 $\mathrm{kg} / \mathrm{ha}$, and reaching the position of largest soybean producer in the country in the 1999/00 crop, according to figure 1 (CONAB, 2017; SÁ; ALBANO, 2011).

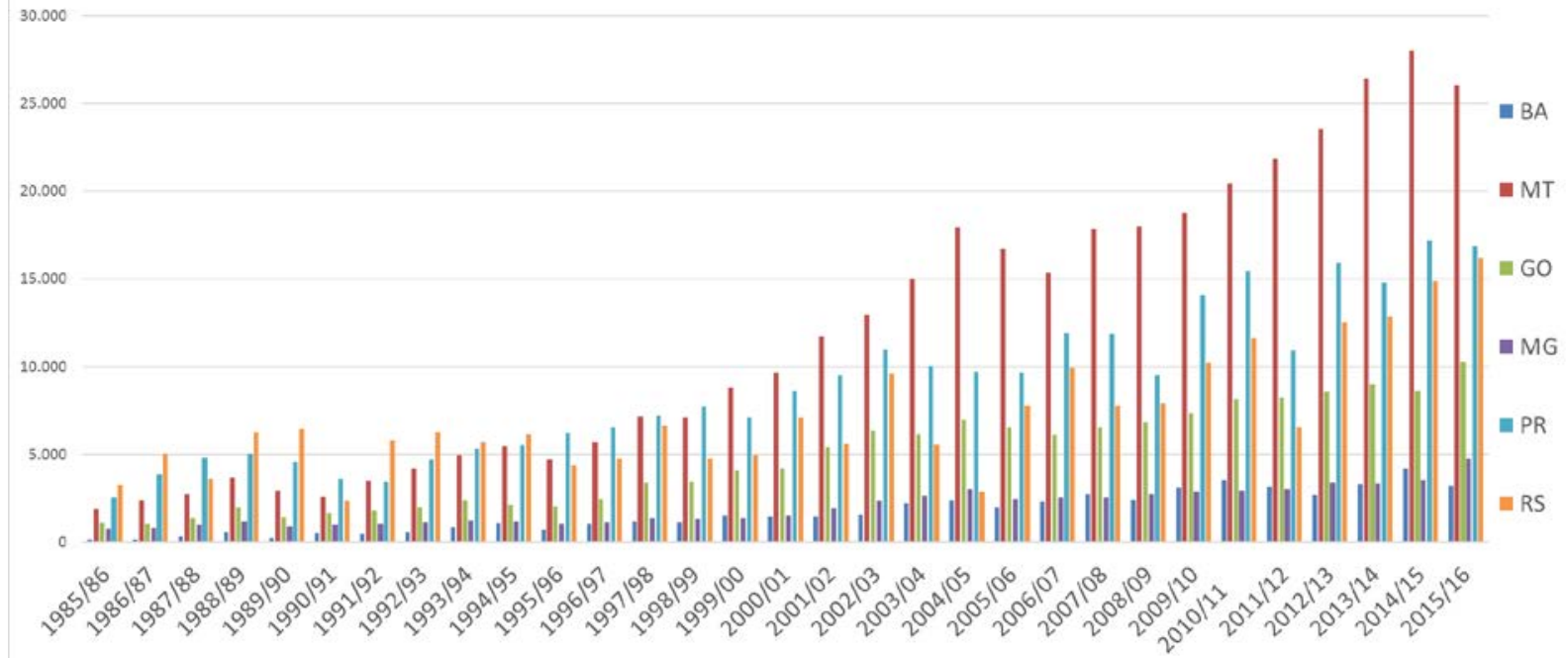

Figure 1: Evolution of Soybean Production: 1985 - 2015. Source: Adapted from (CONAB, 2017).

This growth was made possible by the availability of 200 million hectares of arable land, with favorable climatic conditions and predictable precipitation patterns, together with the public financing policies for timber, livestock, and soybean exploitation (ARVOR et al., 2010).

According to the Brazilian Association of Vegetable Oil Industries - ABIOVE (2017), the soybean complex has a great role for the development of the Brazilian economy, which in 2011 generated more than 1.5 million jobs in the 17 states of the 
INDEPENDENT JOURNAL OF MANAGEMENT \& PRODUCTION (IJM\&P)

http://www.ijmp.jor.br

v. 9, n. 5, Special Edition IFLOG 2017

ISSN: 2236-269X

DOI: 10.14807/ijmp.v9i5.812

federation. Considering investments as technologies, increased new areas for planting, as well as growth of the grain processing industry, promoted improved life of the population.

In the social aspect, that is, for economic and social development, agriculture does not yet add enough value in its primary production, according to Vituri (2010). It has greatly contributed to the generation of employment, being an important link growth and economic development. This is because it is the driving force behind the activities for the industry and services sector.

Industrial modernization is a consequence of agriculture's contribution to economic development, given this optimism in agriculture, Souza (2005) argues that there may be a positive correlation between agricultural growth and growth in other sectors.

Before the understanding, soybeans, the main product produced and marketed in Brazil, help in the positive influence in the other sectors, improving the quality of life, as well as raising the indices of education and health, mainly in the main municipalities that are the largest producers of grains.

\section{METHODOLOGY}

In order to elucidate the contributions of soybean production in the Mato Grosso do Sul municipalities, a survey was carried out in the databases of the Brazilian Institute of Geography and Statistics (IBGE), Portal AliceWeb of the Ministry of Industry and Foreign Trade and Services (MDIC), in the PRODES Project Portal of the Institute of Space Research (INPE) and the Federation of Industry Portal of Rio de Janeiro (FIRJAN). According to Table 1, the data were organized in SPSS $^{\circledR}$ software (Statistical Package for the Social Sciences) version 23.

Subsequently, the data were treated quantitatively through the technique of Principal Component Analysis through SPSS ${ }^{\circledR}$ software.

The data collected refer to the 141 municipalities that make up the State of Mato Grosso.

In view of the need to reduce the asymmetry between the values of the variables, the data transformation was performed using $\log (x)$. The transformation was necessary considering that the values of the variables Population, Area 
occupation with soybean, GDP per capita, Value of Production, Total Exported, Quantity Produced, Area of Forest and Production of $\mathrm{CO}_{2}$ were atypical to the values of the variables IFDM - Education, IFDM - Employment \& Income, IFDM - Health and IDR, so it is necessary to transform the values to correct any problems.

Due to the number of variables used to verify the contribution promoted by soybean production in the municipalities of Mato Grosso, the factor analysis method was used to identify the main variables.

The factorial analysis proposes to reduce the number of variables by the extraction of independent factors, so that a better explanation of the relationship between the original variables occurs, avoiding correlational problems and decreasing the relevance of endogeneity (HAIR, 2006).

Table 1: Variables and data source used in the research.

\begin{tabular}{|c|c|}
\hline Variables & Source \\
\hline Populations (hab.) & \\
\hline Occupation of the area with soybean (ha) & IBGE \\
\hline GDP per capita (US\$) & \\
\hline $\begin{array}{l}\text { Value of Production (Thousand US\$) } \\
\text { Total Exported (US\$) } \\
\text { Quantity Produced (ton.) }\end{array}$ & AliceWeb \\
\hline IFDM - Education & \\
\hline $\begin{array}{l}\text { IFDM - Employment \& Income } \\
\text { IFDM - Health }\end{array}$ & FIRJAN \\
\hline $\begin{array}{l}\text { Area of the Municipality (ha) } \\
\text { Forest Area }\left(\mathrm{Km}^{2}\right)\end{array}$ & INPE \\
\hline IDR & (CHIOVETO, 2014) \\
\hline Production of $\mathrm{CO}_{2}$ Soybean (ton.) & (LINDOSO, 2009) \\
\hline
\end{tabular}

The factor analysis method can be expressed by the mathematical expression as a linear combination between the variables $\left(X_{i}\right)$ and $k$ common factors $(F)$ :

$$
X_{i}=A_{i 1} F_{1}+A_{i 2} F_{2}+\ldots+A_{i k} F_{k}+\varepsilon_{i}
$$

Where,

$A_{i k}$ - Multiple regression coefficient for variable i, factor $\mathrm{k}$.

$F_{k}$ - Uncorrelated common factor $\left(\mu=0\right.$ e $\left.\sigma^{2}=1\right)$

$\varepsilon_{i}$ - Error that captures the specific variation not explained by the linear combination of the factorial loads with the common factors. 
Hair (2006) describes the steps to be followed for the application of the factorial analysis: the assembly of the correlation matrix, the extraction of the initial factors, the factor rotation, and the calculation of the factorial scores.

Stevens (2009) suggests that the correlation matrix is constructed using the sample correlation matrix from which the extracted values are organized in a decreasing manner.

The extraction of the initial factors is obtained through the main components method, being observed if the factors are obtained in order to maximize the total variance attributed to each of the factors and if they are obtained independently between them (STEVENS, 2009).

For Hair (2006), to determine the amount of factors necessary to represent the dataset, only the factors whose characteristic root was greater than the unit were considered.

The coefficient of correlation between each of the original variables and each of the factors is now described by the factorial load, while the commonality of the variable, equivalent to the square of the factorial loads, represents the relative contribution of each factor to the total variance of a variable (FIELD, 2009). In this sense, the community has for factorial analysis a similar meaning to the coefficient of determination of the regression.

According to Hair (2006), the most appropriate method is the orthogonal varimax rotation, because it facilitates the interpretation of factorial loads by minimizing the number of variables that have a high weight in one factor.

Thus, each of the subsets of original variables becomes more associated with a given factor. Stevens (2009) points out that the rotation does not change the values of commonalities, and the proportion of the variance explained by the set of factors is the same before and after the rotation.

Factor rotation is used to improve the interpretation of the solution. The objective is to find factors that have high "loadings" for some variables and low ones for others. The interpretation of each factor is done in function of the variables for which it has high "loadings". 
After performing the factor rotation, the factorial score calculation is started. Hair (2006) suggests that the procedure is similar to a regression. When using the factorial loads of variables as estimated parameters of the equation and multiplying them by the values of the variables that compose the factor, we obtain the estimated value for the dependent variable, in this case, the factor score. Algebraically, the general expression for the estimation of the $\mathrm{j}$-th factor is given by:

$$
F_{j}=W_{j 1} X_{1}+W_{j 2} X_{2}+W_{j 3} X_{3} \ldots+W_{j p} X_{p}
$$

In which, $W_{j p}$ are the coefficients of the factorial scores and $X_{p}$ is the number of variables.

Following the calculation of the factor score, the next step is to verify the adequacy of the factorial analysis. To test the suitability of the factorial analysis model, the Kaiser-Meyer-Olkin (KMO) statistic and the Bartlett Sphericity Test (TEB) are used (FIELD, 2009; HAIR, 2006; STEVENS, 2009).

The KMO test is a correlation coefficient that demonstrates the existence or not of observed correlation between the selected variables. Hair (2006) points out that the values of this test vary from 0 to 1 , small values of $\mathrm{KMO}(\mathrm{KMO}<0.50)$ indicate the non-suitability of the analysis.

The TEB allows us to reject the null hypothesis according to which the correlation matrix would be equal to the identity matrix, that is, without significant correlations.

\section{RESULTS AND DISCUSSION}

The Factor Analysis aims to verify the dimensions that underlie the questions investigated. To use Factor Analysis, it is necessary to verify if some assumptions are met, initially check the Bartlett sphericity test and the Kaiser Meyer-Olkin (KMO) sample adequacy measure.

The sample suitability measure compares the correlation coefficients observed with the partial correlation coefficients, varying between 0 and 1 , whereby, the closer to 1 , the better the sample. In this analysis, the value 0.782 was found, indicating a good sample adequacy, as shown in Table 2.

The Factorial Analysis implemented was of the exploratory type and allowed to obtain three dimensions. 
INDEPENDENT JOURNAL OF MANAGEMENT \& PRODUCTION (IJM\&P)

http://www.ijmp.jor.br

v. 9, n. 5, Special Edition IFLOG 2017

ISSN: 2236-269X

DOI: 10.14807/ijmp.v9i5.812

The values of Table 2, present the information that allows us to select the number of components to retain. It is observed that the eigenvalues found are higher than 1 , and in the set, explain $74.25 \%$ of the total variation of the variables under analysis. It should, therefore, be considered three components.

The variables that explain component 1 , according to Table 2, suggest a strong relation with the effects of soybean production, considering the high variance index of the variables LN Soybean Area (0.971), LN CO 2 (0.970), LN Production (0.967), LN Production Value (0.960) and IDR (0.747).

The variables grouped in component 1 are directly related to soybean production since the volume of production depends on the area planted to soybeans, which in turn impacts on $\mathrm{CO}_{2}$ emissions and on the value of production, which in turn promotes the elevation of IDR (SOUZA, 2005; LINDOSO, 2009; ARVOR et al., 2010; CHIOVETO, 2014; BINI, 2016).

Component 2 can be explained by the variables related to social development indicators (IFDM Education (0.745), IFDM Health (0.726), IFDM Employment and Income (0.634)) and by the variable related to economic development indicators GDP per capita (0.609) and LN Exports (0.546).

It is worth noting that the variables of the social indicators presented a greater variance than the variables for the economic indicators. This suggests that the soybean production promotes a more pronounced improvement in the social indicators on the municipalities where soybean production occurs, similar to what was also observed in the studies of Vituri (2010); Anholeto; Massuquetti (2014); ABIOVE (2017).

Finally, component 3 is related to the variables LN Area of the Municipality (0.880); LN Mata (0.807) and LN Population (0.602) suggesting a reading of the Demographic Factors.

Considering the variances presented above, it can be seen that soybean production is more frequent in municipalities that have larger territorial extensions, which would facilitate the expansion of areas for cultivation, as well as allow to comply with environmental legislation, regarding the area of the preservation and forests native. On the other hand, as the high technology used in the machines and equipment, the use of direct labor is relatively low, justifying the low preference for 
more populous municipalities, according to the studies of Bernardi al. (2014); Hirakuri et al. (2014); WWF (2014).

To name the components, it was necessary to observe the loadings of each variable in each extracted component, Table 2 displays the matrix of the rotating components, where we can verify the correlation between each one of the variables with each one of the components extracted. The meaning of each component lies in the strongest correlations. Only strongest correlations in each component are displayed for the purpose of clarity in interpreting the table.

Thus, Factorial Analysis allowed to identify the most important variables, and to group them in main components, so that they will be denominated as Production Factor, Socioeconomic Factor, and Demographic Factor.

Table 2: Rotational Component Matrix

\begin{tabular}{l|c|c|c|c}
\hline \multicolumn{1}{c}{ Variables } & \multicolumn{2}{|c}{ Component } & Communalities \\
\cline { 2 - 4 } & Production & Socioeconomic & Demographic & \\
\hline IDFM_Employment and & & 0,634 & 0,622 \\
Income & & 0,745 & 0,594 \\
IFDM_Education & & 0,726 & & 0,583 \\
IFDM_Health & 0,747 & & & 0,727 \\
IDR & & & 0,602 & 0,524 \\
LN Population & & & 0,880 & 0,827 \\
LN Area of the Municipality & 0,971 & & & 0,972 \\
LN Area of the Soybean & & 0,609 & 0,680 \\
LN GDP Per Capita & 0,960 & & & 0,933 \\
LN Value of the Production & & 0,546 & & 0,593 \\
LN Exportation & 0,967 & & 0,807 & 0,965 \\
LN Production & & & 0,660 \\
LN Forest & & & 0,973 \\
LN CO 2 & 0,970 & & & \\
\hline
\end{tabular}

Extraction method: Principal components. Varimax rotation with Keiser Normalization. Extraction criterion: eigenvalue higher than 1 . Total variance explained by extracted components: $74,25 \%$ $\mathrm{KMO}=0,782$

\section{CONCLUSIONS}

The growing world demand for soybean allowed the State of Mato Grosso, by its vocation, to expand the area, production, and productivity of soybeans. However, this expansion brought with it changes in the productive structure, which in turn led to changes in the environmental, economic, and social spheres in all municipalities of Mato Grosso.

Due to the large number of variables used, we chose to use a factor reduction methodology to identify which variables are most affected by soybean production in the municipalities of Mato Grosso 
The applied methodology allowed us to analyze several aspects related to soybean cultivation in the municipalities of Mato Grosso in a way that reduced the number of data to a more manageable set while retaining the maximum possible information.

The results indicate the grouping of the variables into three factors.

The variables IDR, LN Soybean Area, LN Production Value, LN Production, and $\mathrm{LN} \mathrm{CO} 2$ make up the Production Factor, and the positive correlation found indicates a positive influence on population growth and health quality in the municipality. In this case, it is worth noting that the influence on the variable LN Soybean Area (0.971) is higher than the IDR (0.747), which may indicate that soybean production has a stronger influence on soybean area and an influence on the Rural Development Index (IDR).

In turn, the variables IFDM Education, IFDM Health, IDFM Employment and Income, GDP Per Capita and LN Exportation make up the Socioeconomic Factor. The positive correlation found, indicating that soybean production positively influences the related variables.

The variables LN Population, LN Area of Municipality, and LN forest are associated to the Demographic Factor.

Thus, the anthropic activity resulting from soybean production in the municipalities of Matogrossense positively influenced the production, socioeconomic and demographic factors in the municipalities where the oilseed crop was recorded.

With the development of the study and the results found, the imperative was to carry out a future research with municipalities of the state of Illinois/USA to confront the results found here, and if the variables and factors will present the same correlations.

Thus, the present study is a useful tool for public and private decision-makers regarding the influence that soybean production exerts on production, socioeconomic and demographic factors in Mato Grosso's municipalities.

\section{ACKNOWLEDGMENTS}

Appreciation is extended to the Coordination of Improvement of Higher Education (CAPES) program from the Ministry of Education, the providers of the 
DOI: 10.14807/ijmp.v9i5.812

research grant; and to IFMT for the research support, and the granting of the capacitation license.

\section{REFERENCES}

ABIOVE, (2012) Importância Econômica e Social da Cadeia Produtiva de Oleaginosa. Disponível em:

$<$ http://www.abiove.org.br/site/index.php?page=importancia-economica-esocial\&area=NCOyLTI>. Acesso em: 7 out. 2017.

ANHOLETO, C. D.; MASSUQUETTI, A. (2014) A Soja Brasileira e Gaúcha no Período 1994-2010: Uma Análise da Produção, Exportação, Renda e Emprego.

Revista Economia e Desenvolvimento, v. 13, n. 2, p. 379-404.

ARVOR, D. et al. (2010) A evolução do setor soja no Mato Grosso. Revista FrancoBrasileira de Geografia, n. 10.

BERNARDI, A. C. C.; NAIME, J. M.; RESENDE, Á. V.; BASSOI, L. H.; INAMASU, R. Y. (2014) Agricultura de precisão: resultados de um novo olhar. Brasília: EMBRAPA.

BINI, F. C. (2016) Análise da Performance Ambiental e a Capacitação Profissional Rural na Produção de Soja e Milho no Estado de Mato Grosso. Dissertação-Bauru: Universidade Estadual Paulista.

CAVALETT, O.; ORTEGA, E. (2009) Emergy, nutrients balance, and economic assessment of soybean production and industrialization in Brazil. Journal of Cleaner Production, v. 17, n. 8, p. 762-771.

CHIOVETO, M. O. T. (2014) Desenvolvimento Rural no Mato Grosso e seus Biomas. Tese-Toledo: Universidade do Oeste do Paraná.

CONAB, C. N. A. (2017) Séries Históricas de Área Plantada, Produtividade e Produção, Relativas às Safras 1976/77 a 2015/16 de Grãos. Disponível em: $<$ http://www.conab.gov.br/conteudos.php?a=1252\&t=2\&Pagina_objcmsconteudos=3 \#A_objcmsconteudos>. Acesso em: 26 abr. 2017

FAGUNDES, M. B. B.; SIQUEIRA, R. P. (2013) Caracterização do Sistema Agroindustrial da Soja em Mato Grosso do Sul. Revista de Política Agrícola, v. 22, n. 3, p. 58-72.

FAS/USDA (2016). World Agricultural Production: Circular Series July 2016. Washington: USDA -United States Department of Agriculture. Disponível em: $<$ http://apps.fas.usda.gov/psdonline/circulars/production.pdf>. Acesso em: 21 jul. 2016.

FIELD, A. (2009) Descobrindo a Estatística usando o SPSS. Traducao Lorí Viali. $2^{\mathrm{a}}$ ed. Porto Alegre: Artmed.

GIBBS, H. K. et al. (2015) Brazil's Soy Moratorium. Science, v. 347, n. 6220, p. 377-378.

HAIR, J. F. (ED.) (2006) Multivariate data analysis. 6th. ed. Upper Saddle River, N.J: Pearson Prentice Hall. 
HIRAKURI, M. H.; CASTRO, C.; FRANCHINI, J. C.; DEBIASI, H.; PROCÓPIO, S. O.; BALBINOT JUNIOR, A. A. (2014) Indicadores de Sustentabilidade da Cadeia Produtiva da Soja no Brasil. Londrina: Embrapa Soja.

KUMAGAI, E.; SAMESHIMA, R. (2014) Genotypic Differences in Soybean Yield Responses tolncreasing Temperature in a Cool Climate are Related to Maturity Group. Agricultural and Forest Meteorology, v. 198-199, p. 265-272.

LINDOSO, D. (2009) Pegada Climática do Uso da Terra: Um diagnóstico do dilema entre o modelo de desenvolvimento agropecuário mato-grossense e as mudanças climáticas no período de 2001-2007. Dissertação-Brasília:

Universidade de Brasília.

LOPES, H. S.; FERREIRA, R. C.; LIMA, R. S. (2015) Logísitica da Soja Brasileira para Exportação: Modelo de Otimização de Custos Logísticos. XXIX Congresso de Pesquisa e Ensino em Transportes. Anais... In: XXIX ANPET. Ouro Preto: Associação Nacional de Pesquisa e Ensino em Transportes - ANPET.

LUEDEMANN, M. S. (2009) O Desenvolvimento do Agronegócio no Brasil Central: Um Estudo sobre Mato Grosso. XII Encuentro de Geógrafos de América Latina. Anais... In: XII EGAL CAMINANDO EN UNA AMÉRICA LATINA EM TRANSFORMACIÓN. Montevidéu: Easy Planner.

MDIC, S. A. (2016) Sistema de análise das informações de comércio exterior via internet do Ministério do Desenvolvimento, Indústria e Comércio Exterior. Disponível em: <http://aliceweb.mdic.gov.br//consulta-ncm/consultar>. Acesso em: 1 abr. 2016.

PAULA, S. R.; FAVERET FILHO, P. (1998) Panorama do Complexo Soja. BNDES Setorial, v. 8, p. 119-152.

PRUDÊNCIO DA SILVA, V. et al. (2010) Variability in environmental impacts of Brazilian soybean according to crop production and transport scenarios. Journal of Environmental Management, v. 91, n. 9, p. 1831-1839.

RAUCCI, G. S. et al. (2015) Greenhouse gas assessment of Brazilian soybean production: a case study of Mato Grosso State. Journal of Cleaner Production, v. 96, p. 418-425.

RODRIGUES, W. (2005) Valoração econômica dos impactos ambientais de tecnologias de plantio em região de Cerrados. Revista de Economia e Sociologia Rural, v. 43, n. 1, p. 135-153.

SÁ, A. J.; ALBANO, G. P. (2011) Globalização da Agricultura: Multinacionais no Campo Brasileiro. Revista de Geografia (UFPE), v. 28, n. 1, p. 54-80.

SOARES, A. F. (2016) Requisitos Ambientais no Mercado de Soja Brasileiro: Descrição e Avaliação de Impacto. Dissertação-Piracicaba: USP/ Escola Superior de Agricultura Luiz de Queiroz.

SOUZA, N. J. (2005) Desenvolvimento Econômico. 5. ed. São Paulo: Atlas. STEVENS, J. (2009) Applied multivariate statistics for the social sciences. 5th ed ed. New York: Routledge.

TEIXEIRA, M. D. J.; FARIA, A. M. M.; ZAVALA, A. A. (2013) Emissões Antrópicas de Gases de Efeito Estufa (GEE) e Referenciais para Política de Mitigação das 
Emissões em Mato Grosso (Brasil). Revista Eletrônica Documento Monumento REDM, v. 10, n. 1, p. 307-323.

VITURI, M. N. (2010) Um Estudo Baseado Nos Indicadores do Setor Agropecuário e o Desenvolvimento Socioeconômico nos Municípios do Estado de Mato Grosso do Sul. Dissertação-Campo Grande: Universidade Federal de Mato Grosso do Sul.

WWF (2014) The growth of Soy: Impacts and Solutions. [s.I: s.n.]. Disponível em: <http://www.wwf.org.br/informacoes/?38423/A-expanso-da-soja>. Acesso em: 28 jul. 2017.

ZHU, Q.; SARKIS, J. (2004) Relationships between operational practices and performance among early adopters of green supply chain management practices in Chinese manufacturing enterprises. Journal of Operations Management, v. 22, n. 3, p. 265-289. 